\title{
EVALUATION OF USING A COMBINATION OF SIMULATED AND EXPERIMENTAL DATA TO PREDICT DRAFT FORCE OF A MOLDBOARDPLOW
}

\begin{abstract}
Abdulwahed M. Aboukarima*
ABSTRACT

Information is required on draft force for tillage implements as it plays an important role in design and development of such implements. Due to the complexity of draft force prediction models of the moldboard plow, there is a need to develop a simple draft prediction model of the moldboard plow, as affected by soil properties and working conditions. In this research, two models were implemented. The first one was by artificial neural network (ANN) and the second was by a multiple linear regression (MLR). The required draft data were obtained by the available Excel spreadsheet. The soil parameters required in the spreadsheet were obtained from experimental work at different sites in Saudi Arabia. For generating draft data, the plowing depths and the plowing speeds were assumed. All combinations were addressed and the total data were 2268 rows. However, 2172 rows were used to build the ANN and MLR models for predicting draft of a moldboard plow. Meanwhile, 96 data points were used to test the models. The mean relative error (MRE) between simulated and predicted values, using regression draft equation and ANN model were $1.86 \%$ and $-8.966 \%$, respectively during testing phase. The performance of the two models was validated by a field experiment data and points from literature. MRE values between measured and predicted values of validation data using field data were $5.19 \%$ and $12.32 \%$ when using ANN and MLR models, respectively. The encouraging results can push to utilize the developed models to be a tool for evaluation in farm machinery management process.
\end{abstract}

* Researcher, Agricultural Engineering Research Institute, Agriculture Research Centre and currently he is working as Assistant Professor at Shaqra University, Saudi Arabia. 


\section{INTRODUCTION}

$N$ oil tillage by moldboard plow is one of the fundamental phases of agricultural production (Formato et al., 2005) since it has been encountered with two problems; the possibility of plow pan formation which could have negative effects on vertical water movement into the soil and low penetration rate (Abas et al., 2008). On the other hand, information is required on draft force for such plow (Kheiralla et al., 2004) as it plays an important role in design and development of it (KarimiInchebron et al., 2012). Moreover, the draft force required to pull a tillage implement is of great importance since it determines fuel consumption and the tractor power required (Arvidsson and Hillerstrom, 2010).

It is known that the draft force of a moldboard plow depends on the geometry of the plow body as well as soil properties as its hardness, density, friction and adhesion (Godwin et al., 2007). In addition, the draft is dependent on operating factors such as depth of plowing, plow speed and the number of bodies in use. So, different studies were conducted to assess such affecting factors on the draft force of a moldboard plow. Besides, different draft models for moldboard plow were developed to calculate such force by the help of soil mechanic theory as the study conducted by (Godwin et al., 2007), or by regression analysis (Gee-Clough et al., 1978; Oskoui and Witney, 1982; Oskoui et al., 1982; Elbanna, 1989; El Khadrawy, 1990; Elbanna, 1992; Kheiralla et al. 2004) or by artificial neural networks as the study conducted by Aboukarima (2004). However, several authors found ANN predictions for draft, pull and energy requirements of tillage implements to be an effective tool, as shown in studies by Hassan and Tohmaz (1995), Tohmaz and Hassan (1995), Kushwaha and Zhang (1997), Zhang and Kushawaha (1999), Al-Janobi et al. (2001), Aboukarima et al. (2003), El Awady et al. (2003), Aboukarima (2007), Aboukarima and Saad (2006), El Awady et al. (2004), Roul et al. (2009) and Al-Janobi et al. (2010). Also, the analytical and the finite element methods have been used to investigate soil cutting process (Mouazen and Neményi, 1998). Such models are essential for improving the design and selection of moldboard plows (Aluko and 
Seig, 2000). Adding, traditional plow design and manufacture have been based on empirical methods and experiments (Shrestha et al., 2001), depending on the type of soil in the different areas.

There are different research works to study the impact of soil properties such as soil bulk density, soil moisture content, etc. on the draft of tillage implements. These influencing factors were the main axis of interest of previous research, which adapted field experiments to understand how these factors affect this draft (Mouazen and Ramon, 2002). Addition result showed that soil moisture content is an important variable to draft of a tillage implement, however, a dry soil requires an excessive power and also accelerates wear of the cutting edges (Gill and Vanden Berg, 1968), where, they indicated that in soil bin tests, an observed increase of moisture content from 9.1 to $11.7 \%(\mathrm{db})$ reduced the specific draft in a fine sandy loam by 15 to $35 \%$. Meanwhile, they reported a 15 to $35 \%$ increase in draft when the bulk density of a fine sandy loam was changed from $1680 \mathrm{~kg} / \mathrm{m}^{3}$ to $1830 \mathrm{~kg} / \mathrm{m}^{3}$. In the same findings, Mouazen et al. (2003) reported that draft for a tillage implement decreased with increasing moisture content.

Arvidsson et al. (2004) presented a study to measure the specific draft (force per cross-sectional area of worked soil) for a moldboard plow. The plow was set to working depth of $13 \mathrm{~cm}$. Plowing was carried out at three different water contents ("Wet', "Moist" and "Dry") on two sites. The results showed that draft increased with decreasing soil water content.

Tong and Moayad (2006) found that from field experiments with a chisel plow the draft increased with increasing soil bulk density. KarimiInchebron et al. (2012) measured draft for moldboard plow in different depths $(10,15$ and $20 \mathrm{~cm})$ and soil moisture contents (16-18\%), $(19-22 \%)$ and $(23-25 \% \mathrm{db})$. The results indicated that plowing depth and soil moisture content had significant effect $(\mathrm{P}<0.01)$ on the draft. It was also found that draft decreased significantly with increase in the soil moisture content.

Summers et al. (1986) studied the effects of plowing speed and depth on moldboard plow draft in clay loam soil and silt loam soil. Their measured drafts in clay loam soil and silt loam soil were 7 and 13\%, respectively, lower than the ASAE Standard (ASAE Standards, 1984). 
Khadr (2008) reported that by increasing the plowing speed from 0.89 to $1.62 \mathrm{~m} / \mathrm{s}$ for moldboard plow, the draft increased from $18.82 \mathrm{kN}$ to 21.66 $\mathrm{kN}$ in clay soil.

Abas et al. (2008) evaluated the effects of five plow share types (deepsuck share (control), trapezium-shaped share with/without share point, and serrated share with/without share point) under two soil moisture contents ( 0.85 and 0.55 plastic limit (PL)), and two plowing depths (15 and $20 \mathrm{~cm}$ ) on draft of the moldboard plow in a silty clay loam soil. The results showed that when soil moisture content was reduced from optimum value for plowing $(0.85 \mathrm{PL})$ to dry condition $(0.55 \mathrm{PL})$; the draft of plow with deep-suck share equipped with share point significantly increased (by 28\%). Also, increasing the plowing depth by 33\%, draft significantly increased by $33 \%$.

Godwin et al. (1981) showed that there are changes in the magnitude of the soil force with depth at two types of soil and the draft increases in an essentially linear matter with increasing forward speed.

Nadre and Datta (1991) mentioned that the draft increased with increasing in the depth of operation for moldboard plow. Imara (1996) developed equation to predict drawbar pull for moldboard plow using multiple linear regression and the affecting variables were forward speed, soil moisture content and plowing depth. The coefficients of soil moisture content in his equation was negative that mean increasing soil moisture content decreasing drawbar pull for specific case of forward speed and plowing depth. On the other hand, coefficients of forward speed and plowing depth in his equation were positive.

Gebresenbet et al. (1997) reported that there were differences in values of the draft force for a plow measured in fields of clay and sandy soil. Summers et al. (1986) showed the greater draft requirement for silt loam compared with other soils was due to the higher relative soil strength as judged by cone index values for moldboard plow.

Ward (1995) reported that there was no single model that adequately defines the impact of the various parameters on plow draft, as there was considerable variation from soil to soil. Huijsmans et al. (1998) mentioned that in general, a higher draft force was required on the clay soil than on sand soil for trailing-foot and shallow injection equipment. Higher soil moisture content led to a lower draft force requirement. 
Al-Janobi and Al-Suhaibani (1998) applied field experiments to measure draft of a moldboard plow in sandy loam soil, and when they applied the proposed draft model by Harrigan and Rotz (1995) on their data, they found that the measured draft was close to the predicted draft and they attributed the difference between measured and predicted to the soil conditions.

Kheiralla et al. (2004) conducted a field experiment in sandy clay loam soil to measure draft of a moldboard and the effects of plowing speed and plowing depth upon the measured draft were investigated. A polynomial draft from orthogonal regression analyses was formulated based on linear and quadratic functions of plowing speed and plowing depth. The predicted moldboard plow draft was $4 \%$ lower than the draft computed with the ASAE Standard (ASAE Standards, 1997).

Rahman et al. (2011) developed a neural network model to predict energy requirement of a tillage tool from the laboratory data. The neural network model was trained and tested with soil moisture content, plowing depth and forward operating speed as input parameters. The measured energy requirement for a tillage tool in silty clay loam soil was used as output parameter. Their results showed that the variation of measured and predicted energy requirement was small.

Roul et al. (2009) applied a 5-9-1 artificial neural network (ANN) model with a back propagation learning algorithm to predict draft requirements of different tillage implements in a sandy clay loam soil. The input parameters were width of cut, depth of operation, speed of operation, soil moisture content and soil bulk density. The results indicated that the developed ANN model for draft prediction could be considered as an alternative and practical tool for predicting draft requirement of tillage implements under the selected experimental conditions in sandy clay loam soils.

There is a suggestion to conduct studies to measure draft and energy requirements of tillage implements under various soil conditions in the developed nations of the world (Manuwa and Ogunlami, 2010); this is due to the complexity of tillage implements draft force prediction. Thus, in the light of the aforementioned, it is clear that there is a need of a simple draft model for moldboard plow including soil properties and working condition. So, the aim of this research was to implement an 
ANN model for draft force prediction of a moldboard plow using the combination of experimental and simulation data. For compression, a multiple linear regression technique was used to build the draft model. The two models will be validated by data from actual field experiment and data from literature.

\section{MATERIALS AND METHODS}

Field experiment site and soil properties data

Collecting soil samples were carried out from different sites in Saudi Arabia, during year of 2012. The purpose was to determine soil cohesion, soil moisture content, soil internal friction angle and soil bulk density. The latitude, longitude and altitude of each site are shown in Table (1). The samples were obtained in undisturbed condition using soil cylinder $0.16 \mathrm{~m}$ in height and $0.08 \mathrm{~m}$ in diameter. The soil samples were weighed using a balance and the weight of each sample was recorded. Then the samples were placed in an electric oven, maintained at $110^{\circ} \mathrm{C}$ for $48 \mathrm{~h}$. The dried soil samples were reweighed and the weight was again recorded. The moisture contents were calculated on a dry weight basis and also soil bulk density values were addressed. In addition, soil from each site was classified by mechanical analysis. All laboratory tests were carried out according to the standard methods. Direct shear box method was used in determining soil cohesion and soil internal friction angle. Levels of soil moisture content similar to the soil moisture content in the field were tested, and for 2 replicates. If the results of 2 replicates for each sample were not close to each other, more tests were repeated to verify the real values of shearing force for that sample. During the shear experiments, soil wet density of the soil was maintained in the range related to soil bulk density. The loading rate during shear tests was constant rate of $0.12 \mathrm{~mm} / \mathrm{min}$. A soil sample was placed in a metal shear box and undergoes a horizontal force and the soil failed by shearing along a plane when the force was applied. Soil-metal friction angle $(\delta)$ was determined using the following formula (Chung et al. 2008),

$\delta=\left[\begin{array}{l}(0.590 \times \text { Sand fraction })+(0.735 \times \text { Silt fraction })+ \\ (0.375 \times \text { Clay fraction })\end{array}\right] \times \phi \ldots$.

Where $\phi$ is the angle of soil-soil friction in deg. Table (1) illustrates soil properties in all the selected sites. 
Table (1). Soil properties in the selected sites.

\begin{tabular}{|c|c|c|c|c|c|c|c|c|c|c|c|}
\hline $\begin{array}{c}\text { Soil } \\
\text { Sample }\end{array}$ & Latitude & Longitude & Altitude & Sand & Silt & Clay & $\begin{array}{l}\text { Soil moisture } \\
\text { content }\end{array}$ & $\begin{array}{c}\text { Soil bulk } \\
\text { density }\end{array}$ & $\begin{array}{c}\text { Soil } \\
\text { cohesion }\end{array}$ & $\begin{array}{l}\text { Angle of internal } \\
\text { friction of soil }\end{array}$ & $\begin{array}{l}\text { Soil-metal friction } \\
\text { angle }\end{array}$ \\
\hline No. & $\left({ }^{\circ} \mathrm{N}\right)$ & $\left({ }^{\circ} \mathrm{E}\right)$ & (m) & $(\%)$ & $(\%)$ & $(\%)$ & $(\%)$ & $\left(\mathrm{g} / \mathrm{cm}^{3}\right)$ & $(\mathrm{kPa})$ & (degree) & (degree) \\
\hline 1 & 26.21 & 43.89 & 644.11 & 72.8 & 15.2 & 12.0 & 2.75 & 1.63 & 15.7 & 42 & 24.90 \\
\hline 2 & 26.41 & 43.82 & 642.36 & 88.8 & 7.2 & 4.0 & 5.62 & 1.98 & 24.5 & 41 & 27.42 \\
\hline 3 & 26.44 & 43.69 & 699.53 & 88.9 & 8.1 & 3.0 & 8.98 & 1.69 & 11.8 & 34 & 21.36 \\
\hline 4 & 26.43 & 43.71 & 689.59 & 84.8 & 10.2 & 5.0 & 8.85 & 1.96 & 18.6 & 44 & 28.39 \\
\hline 5 & 28.40 & 36.87 & 802.34 & 80.6 & 9.4 & 10.0 & 11.20 & 1.60 & 3.9 & 34 & 19.02 \\
\hline 6 & 28.40 & 36.87 & 802.67 & 75.7 & 12.3 & 12.0 & 7.30 & 1.40 & 12.8 & 32 & 18.72 \\
\hline 7 & 28.40 & 36.80 & 799.19 & 68.5 & 17.5 & 14.0 & 10.60 & 1.70 & 33.4 & 37 & 24.34 \\
\hline 8 & 28.40 & 36.78 & 797.59 & 63.6 & 16.4 & 20.0 & 7.50 & 1.70 & 73.6 & 43 & 33.18 \\
\hline 9 & 28.43 & 36.62 & 770.92 & 63.8 & 15.2 & 21.0 & 15.10 & 1.90 & 19.6 & 31 & 17.41 \\
\hline 10 & 24.32 & 47.13 & 465.06 & 82.2 & 9.9 & 7.9 & 1.30 & 1.55 & 7.8 & 38 & 22.02 \\
\hline 11 & 24.18 & 47.22 & 446.84 & 86.4 & 8.8 & 4.8 & 10.65 & 1.66 & 4.9 & 35 & 20.57 \\
\hline 12 & 24.26 & 47.26 & 444.74 & 75.3 & 16.7 & 8.0 & 5.30 & 1.58 & 6.9 & 35 & 20.75 \\
\hline 13 & 24.21 & 47.57 & 400.00 & 71.8 & 17.2 & 11.0 & 4.10 & 1.74 & 41.2 & 43 & 30.30 \\
\hline 14 & 24.20 & 47.56 & 401.61 & 85.7 & 7.3 & 7.0 & 5.36 & 1.95 & 27.5 & 39 & 25.50 \\
\hline 15 & 24.20 & 47.24 & 442.60 & 77.3 & 16.7 & 6.0 & 8.00 & 1.69 & 21.6 & 40 & 26.13 \\
\hline 16 & 20.42 & 44.74 & 702.18 & 74.8 & 17.2 & 8.0 & 7.08 & 1.90 & 19.6 & 39 & 25.27 \\
\hline 17 & 20.43 & 44.73 & 702.93 & 80.3 & 15.7 & 4.0 & 7.50 & 1.47 & 4.9 & 32 & 19.44 \\
\hline 18 & 20.42 & 44.71 & 710.37 & 79.7 & 16.3 & 4.0 & 7.20 & 1.64 & 14.7 & 32 & 20.65 \\
\hline 19 & 20.44 & 44.74 & 698.69 & 84.4 & 12.6 & 3.0 & 10.00 & 1.67 & 13.7 & 32 & 20.55 \\
\hline 20 & 29.99 & 40.12 & 611.06 & 88.8 & 7.2 & 4.0 & 5.77 & 1.80 & 23.5 & 42 & 27.94 \\
\hline 21 & 30.00 & 40.12 & 607.94 & 80.7 & 8.3 & 11.0 & 10.60 & 1.60 & 13.7 & 33 & 19.43 \\
\hline 22 & 29.89 & 38.58 & 609.09 & 83.6 & 11.4 & 5.0 & 5.00 & 1.60 & 11.8 & 42 & 26.09 \\
\hline 23 & 29.89 & 38.57 & 614.94 & 85.2 & 10.8 & 4.0 & 9.30 & 1.40 & 4.9 & 32 & 19.21 \\
\hline 24 & 27.79 & 41.73 & 871.74 & 74.1 & 15.9 & 10.0 & 8.87 & 1.40 & 7.8 & 34 & 19.84 \\
\hline 25 & 27.80 & 41.75 & 870.11 & 77.3 & 13.7 & 9.0 & 9.82 & 1.46 & 22.6 & 32 & 20.52 \\
\hline 26 & 27.80 & 41.75 & 869.90 & 71.7 & 15.3 & 13.0 & 9.67 & 1.72 & 54.0 & 39 & 29.07 \\
\hline 27 & 27.82 & 41.73 & 862.34 & 65.9 & 20.1 & 14.0 & 9.92 & 1.73 & 55.9 & 41 & 30.45 \\
\hline
\end{tabular}




\section{Representing soil texture}

A soil texture index was developed by combining all soil fractionssimilar to that developed by Oskoui and Harvey (1992). However, due to the sand content is the major component in the selected sites, followed by silt then clay, another formula was developed, to calculate soil texture index (STI), as follows:

$$
S T I=\frac{\log \left(S a^{S i}+C C a\right)}{100}
$$

Where $\mathrm{Sa}$ is the percentage of sand content in the soil, $S_{i}$ and $\mathrm{CC}_{\mathrm{a}}$ are the percentages of silt and clay contents in the soil, respectively. Oskoui and Harvey (1992) showed that the STI reflects the effects of all three soil fractions. The STI produces unique numbers for every combination of sand, silt and clay contents.

\section{Field experimental procedure for measuring draft force of a moldboard plow}

Field experiments were conducted during April 2012 in the Agricultural Research and Experimental Farm in Dirab, Riyadh, Saudi Arabia. Longitude, latitude and altitude for the experiment site were $46.65^{\circ} \mathrm{E}$, $24.41^{\circ} \mathrm{N}$ and $575.79 \mathrm{~m}$, respectively. An experimental block about $50 \mathrm{~m}$ long by $3 \mathrm{~m}$ wide was utilized during experiments. A small block of approximately $10 \mathrm{~m}$ long by $3 \mathrm{~m}$ wide, in the beginning of each tested block, was used to enable the tractor and plow to reach a steady state condition of the required plowing speed and plowing depth. Plowing depth was measured as the vertical distance from the top of the undisturbed soil surface to the plow's deepest penetration. In this work, the plowing depth was $15 \mathrm{~cm}$. The horizontal force (draft) was measured using a load cell (model Omega with a capacity of 0-10000 lb) using the method described in (PAES, 2001). The moldboard plow was hitched to a Fendt tractor model 611LS. However, the auxiliary tractor was John Deer tractor model 6615.The draft was recorded within the distance of 40 $\mathrm{m}$. The plowing speed was calculated by measuring of distance of five turns of the tractor rear wheel with time. On the same field, the plow was 
lifted out the ground and the rear tractor was pulled to record the idle draft force. The difference gave the draft of the plow. A moldboard of general purpose type with three bodies in the frame each of width 360 mm (Overum-S, Sweden), model 7073331) was used in this experiment. The plow specifications are depicted in Table (2). Three plowing speeds were obtained by changing tractor gear box gears. Soil properties of the field experiment are shown in Table (3).

\section{Available moldboard draft requirement model}

The moldboard plow geometric factors and the draft force components are shown in Figure (1) (Godwin et al., 2007). The total plow draft (Godwin et al., 2007) force $\mathrm{H}_{\mathrm{t}}$ in $\mathrm{kN}$ is calculated from the following expression:

$$
H_{t}=H_{p}+H_{s}+H_{m c}+H_{e}+H_{c s}+H_{m s}+H_{f s}
$$

where $\mathrm{H}_{\mathrm{p}}$ is the draft force due to the plow point in $\mathrm{kN} ; \mathrm{H}_{\mathrm{s}}$ is the draft force due to the plow share in $\mathrm{kN} ; \mathrm{H}_{\mathrm{mc}}$ is the draft force due to the moldboard soil momentum change and the draft force friction along the moldboard in $\mathrm{kN} ; \mathrm{H}_{\mathrm{e}}$ is the draft force due to the increase in soil potential energy at the moldboard in $\mathrm{kN} ; \mathrm{H}_{\mathrm{cs}}+\mathrm{H}_{\mathrm{ms}}$ are the draft force components arising from friction forces due to lateral forces at the share and moldboard, respectively, in $\mathrm{kN} ; \mathrm{H}_{\mathrm{fs}}$ is the draft force arising from the lateral force at the moldboard due to soil lateral movement in $\mathrm{kN}$.

Table (2). Specifications of the used moldboard plow.

\begin{tabular}{|l|c|}
\hline \multicolumn{1}{|c|}{ Items } & Value \\
\hline Share sweep angle, $\beta\left(^{\circ}\right)$ & 44 \\
\hline Moldboard angle, $\theta\left(^{\circ}\right)$ & 39 \\
\hline Point depth $(\mathrm{cm})$ & 6 \\
\hline Point width $(\mathrm{cm})$ & 7 \\
\hline Rake angle, $\alpha\left(^{\circ}\right)$ & 23 \\
\hline Share width $(\mathrm{cm})$ & 36 \\
\hline Moldboard length $(\mathrm{cm})$ & 87 \\
\hline
\end{tabular}


Table (3). Soil properties and working condition during field experiment.

\begin{tabular}{|c|c|c|c|c|c|c|}
\hline $\begin{array}{c}\text { Soil Moisture } \\
\text { content }\end{array}$ & $\begin{array}{c}\text { Soil bulk } \\
\text { Density }\end{array}$ & $\begin{array}{c}\text { Plowing } \\
\text { depth }\end{array}$ & $\begin{array}{c}\text { Plowing } \\
\text { speed }\end{array}$ & Sand & Silt & Clay \\
\hline$(\% \mathrm{db})$ & $\left(\mathrm{g} / \mathrm{cm}^{3}\right)$ & $(\mathrm{cm})$ & $(\mathrm{km} / \mathrm{h})$ & $(\%)$ & $(\%)$ & $(\%)$ \\
\hline 7.5 & 1.67 & 15 & 2.5 & 84.6 & 12.4 & 3.0 \\
\hline 7.5 & 1.67 & 15 & 3.4 & 84.6 & 12.4 & 3.0 \\
\hline 7.5 & 1.67 & 15 & 5.3 & 84.6 & 12.4 & 3.0 \\
\hline
\end{tabular}

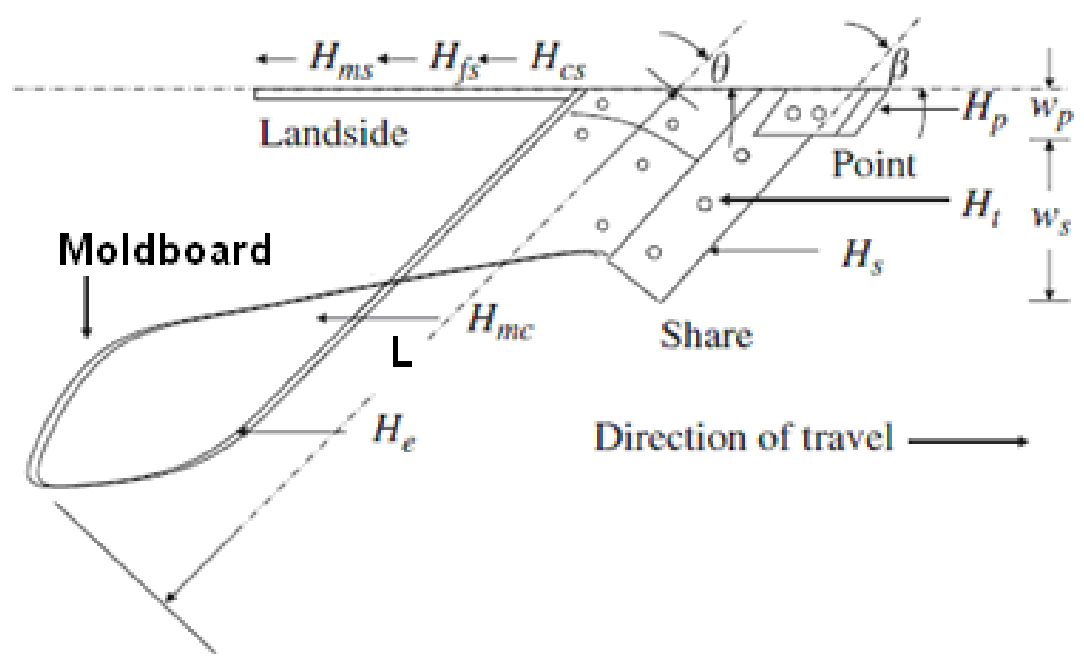

Figure (1). Diagram of the components of the draft force acting on moldboard plow.

The individual components of the draft force are given as follows:

$$
\begin{aligned}
& H_{p}=\left[\begin{array}{c}
\left(\gamma d_{p}{ }^{2} N_{\gamma}+C d_{p} N_{C a}\right)\left(w_{p}+0.55 d_{p}\left(m_{s}-\left(m_{s}-1\right) / 3\right)\right) \\
+\left(\frac{\gamma V^{2} N_{a} d_{p}}{g}\right)\left(w_{p}+0.33 d_{p}\right)
\end{array}\right] \sin \left(\alpha_{p}+\delta\right) . .(4) \\
& H_{s}=\left(\gamma d_{s}{ }^{2} N_{\gamma}+C d_{s} N_{C a}+\frac{\gamma V^{2} N_{a} d_{s}}{g}\right) w_{s} \sin \left(\alpha_{s}+\delta\right) \sin \beta \\
& H_{m c}=(\gamma / g)\left(w_{p} d_{p}+w_{s} d_{s}\right) V^{2}(1-(1-\sin \theta \tan \delta) \cos \theta) \text {. } \\
& H_{e}=2 \gamma\left(w_{p} d_{p}+w_{s} d_{s}\right) d_{s}
\end{aligned}
$$




$$
\begin{aligned}
& H_{c s}=\left(\gamma d_{s}^{2} N_{\gamma}+C d_{s} N_{C a}+\frac{\gamma V^{2} N_{a} d_{s}}{g}\right) w_{s} \sin \left(\alpha_{s}+\delta\right) \cos \beta \tan \delta \\
& H_{m s}=(\gamma / g)\left(w_{p} d_{p}+w_{s} d_{s}\right) V^{2} \sin \theta(1-\sin \theta \tan \delta) \tan \delta \\
& H_{f s}=L \gamma\left(w_{p} d_{p}+w_{s} d_{s}\right) \tan \phi_{s} \tan \delta
\end{aligned}
$$

Where $\gamma$ is soil bulk unit weight in $\mathrm{kN} / \mathrm{m}^{3}$; $\mathrm{C}$ is soil cohesion in $\mathrm{kN} / \mathrm{m}^{2}$; $\mathrm{d}_{\mathrm{p}}$ is depth of plow point in $\mathrm{m}$; $\mathrm{w}_{\mathrm{p}}$ is width of plow point in $\mathrm{m}$; $m_{s}$ is soilrupture distance ratio (the ratio between forward rupture distance and working depth); $\mathrm{V}$ is plow forward velocity in $\mathrm{m} / \mathrm{s} ; \mathrm{g}$ is the acceleration due to gravity in $\mathrm{m} / \mathrm{s}^{2} ; \alpha_{p}$ is point rake angle in deg; $\delta$ is angle of soil to metal friction in deg, $N_{\gamma}, \mathrm{N}_{\mathrm{ca}}$ and $\mathrm{N}_{\mathrm{a}}$ are dimensionless soil parameters, $\mathrm{d}_{\mathrm{s}}$ is depth of plow share in soil in $\mathrm{m} ; \mathrm{w}_{\mathrm{s}}$ is width of plow share in $\mathrm{m} ; \alpha_{s}$ is share rake angle in deg, $\beta$ is angle of share edge to direction of plow motion in deg, $\theta$ is the mean angle of the moldboard to the direction of motion of the plow in deg and $\mathrm{L}$ is the effective length of the moldboard in m. Godwin et al. (2007) developed a spreadsheet (Figure 2) to enable calculations of moldboard draft force to be carried out without a detailed knowledge of all the underlying theory which can involve complex procedures using equations 3 through 10.

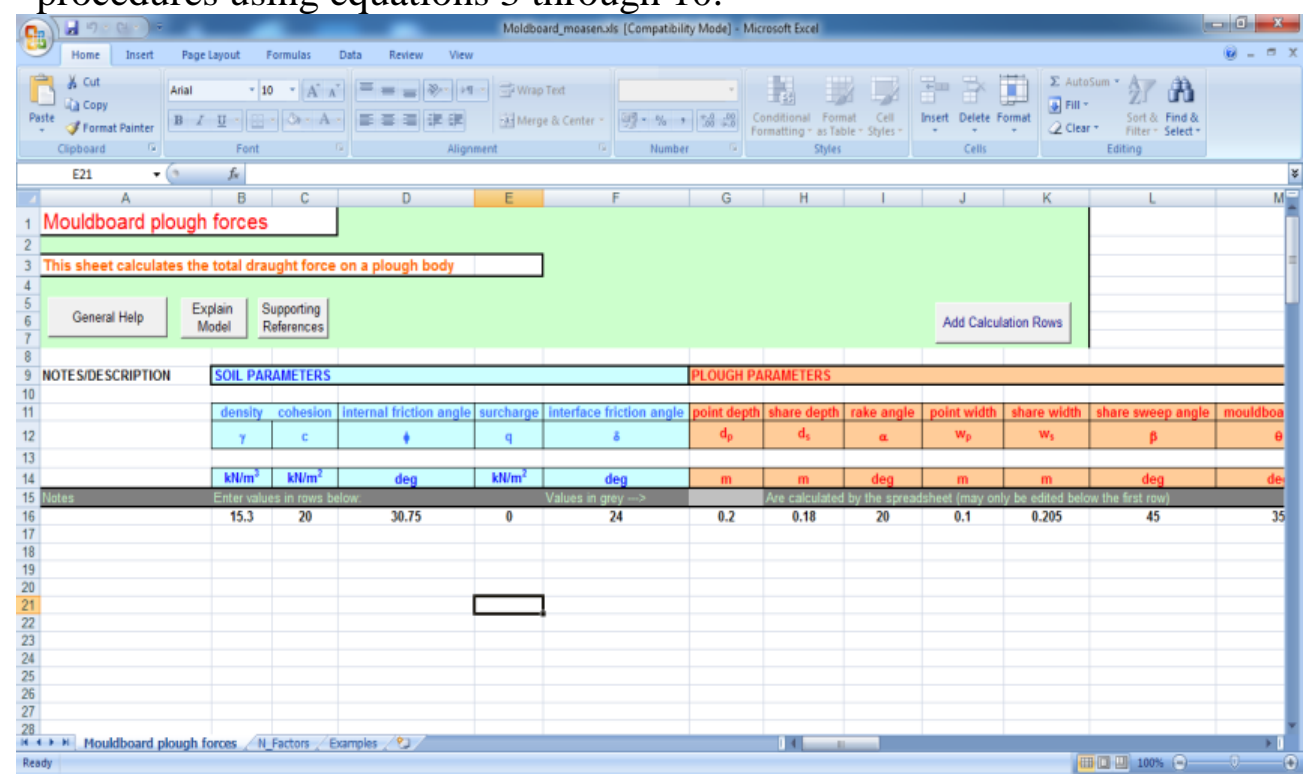

Figure (2). A screenshot of the spreadsheet to enable calculations of moldboard draft (Godwin et al., 2007). 
In this research work, the soil parameters (soil cohesion, soil internal friction angle, soil metal friction angle and soil density) needed in the spreadsheet were obtained from experimental work in different sites. For generating draft data, the assumed plowing depths were $12,14,16,18,20,22$ and $24 \mathrm{~cm}$ and the assumed plowing speeds were $2,2.5,3,3.5,4,4.5,5,5.5,6,6.5,7$ and $7.5 \mathrm{~km} / \mathrm{h}$. The specifications of the moldboard plow are shown in Table (2). All combinations were addressed and the total data were 2268 rows. The simulated draft data were formulated using artificial neural network (ANN) model and regression equation to predict draft of a moldboard plow using less affecting parameters (soil moisture content, soil bulk density, plowing depth and speed and soil texture index).

\section{Artificial neural network model}

In order to design the ANN model, commercial neural network software of QNET 2000 for WINDOWS (Vesta Services, 2000) was used in this research. The ANN used in this study was a standard back-propagation neural network with three layers: an input layer, a hidden layer and an output layer. The neurons in the three layers are connected by weights. The weights connecting input neuron $i$ to hidden neuron $j$ are denoted by $w_{j i}^{h}$, while the weights connecting hidden neuron $j$ to output neuron are denoted by $w_{j}^{o}$. The input of each neuron is the weighted sum of the network inputs, and the output of the neuron is a sigmoid function value based on its inputs. More specially, for the $j$ th hidden neuron (Zhang et al., 2005).

$\left\{\begin{array}{c}n e t_{j}^{h}=\sum_{i=1}^{n} w_{j i}^{h} x_{t-1}+b_{j} \\ y_{j}=f\left(n e t_{j}^{h}\right)\end{array}\right.$,

While for the output neuron 


$$
\left\{\begin{array}{rl}
n e t^{o} & =\sum_{j=1}^{m} w_{j}^{o} y_{j}+c \\
\tilde{x}_{t} & =f\left(n e t^{o}\right)
\end{array},\right.
$$

Where $b_{j}$ and $c$ are thresholds (bias), this network has $n$ neurons in the input layer and $m$ neurons in the hidden layer, $f$ is typically taken to be a sigmoid function, such as the logistic function

$$
f(x)=\frac{1}{1+e^{-x}}
$$

The inputs to this network are soil moisture content, soil bulk density, plowing depth, soil texture index and plowing speed. The output has one $\tilde{x}_{t}$ that is draft of a moldboard plow (kN/body).

Before training, a certain pre-processing steps on the network inputs and targets to make more efficient neural network training was performed. The simulated draft data versus soil moisture content, soil bulk density, plowing depth, soil texture index and plowing speed were fed to an ANN model (a total of 2268) and 96 points of them were selected randomly to be used as testing data set. The training data set used in ANN model was also used to build the regression equation. Prior to their use in the model, the input and the output values were normalized between 0.15 and 0.85 according to the following equation:

$$
T=\frac{\left(t-t_{\min }\right)}{\left(t_{\max }-t_{\min }\right)} \times(0.85-0.15)+0.15
$$

Where $\mathrm{t}$ is the original values of input and output parameters, $\mathrm{T}$ is the normalized value; $t_{\max }$ and $t_{\min }$ are the maximum and minimum values of the input and the output parameters in training data set, respectively which are depicted in Table (4). 
Table (4). The minimum and maximum of inputs and output data for building ANN model.

\begin{tabular}{|c|l|c|c|}
\hline \multicolumn{2}{|c|}{ Parameters } & Minimum & Maximum \\
\hline \multirow{4}{*}{ Inputs } & Soil moisture content $(\% \mathrm{db}$ & 1.3 & 15.1 \\
\cline { 2 - 4 } & Soil bulk density $\left(\mathrm{g} / \mathrm{cm}^{3}\right)$ & 1.4 & 1.98 \\
\cline { 2 - 4 } & Plowing depth $(\mathrm{cm})$ & 12 & 24 \\
\cline { 2 - 4 } & Soil texture index $(----)$ & 0.1403 & 0.3656 \\
\cline { 2 - 4 } & Plowing speed(km/h) & 2 & 7.5 \\
\hline Output & Draft $(\mathrm{kN} /$ body) & 0.64 & 13.2 \\
\hline
\end{tabular}

Different number of neurons in the hidden layer, different values of the learning rate, different values of the momentum, and different transfer functions were investigated (data not shown). The performance of each model was evaluated using correlation coefficient and training error. The best ANN structure and optimum values of the network parameters were obtained on the basis of the lowest training error on training data set by trial and error. Results showed that among the various structures, the best training performance to predict draft belonged to the 5-8-1 structure. Figure (3) illustrates the developed ANN model. Meanwhile, training error during training process versus iterations is shown in Figure (4). The training error was 0.020006 after 200000 epochs and momentum factor was 0.8 and learning rate was 0.002784 .

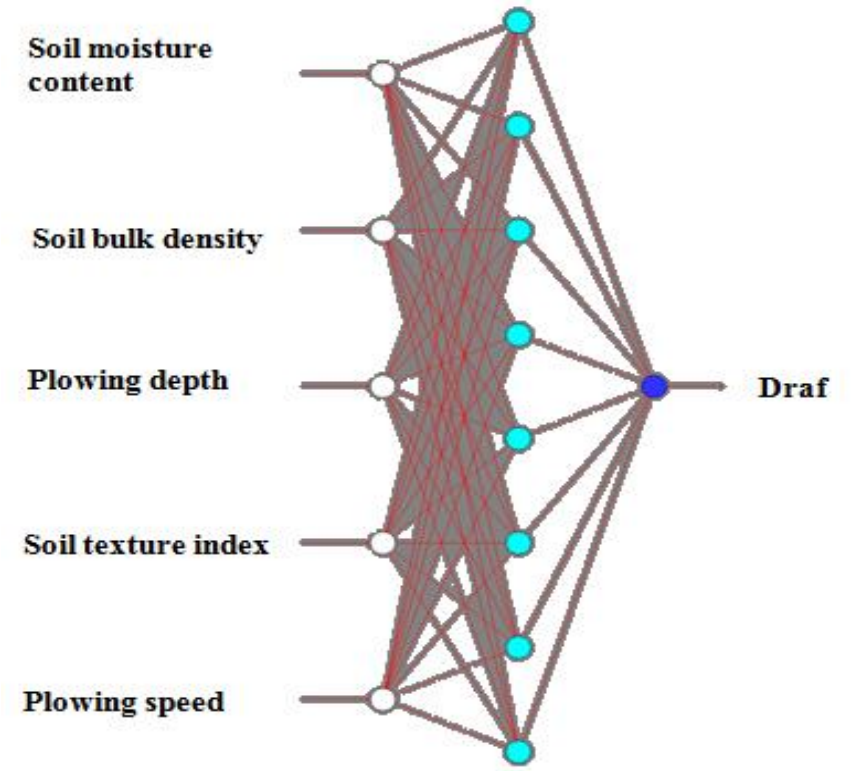

Figure (3). Structure of the ANN used in this study. 


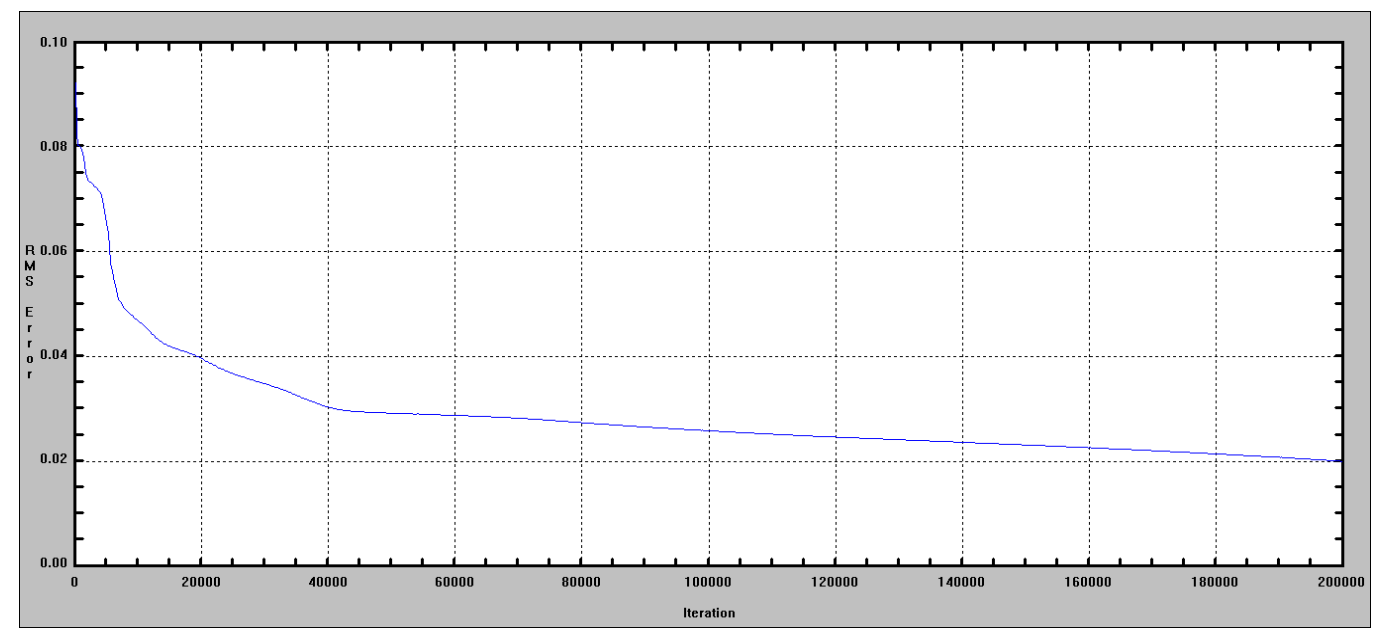

Figure (4). Training error versus iterations during training phase.

\section{Multiple regression model (MLR)}

The general purpose of a multiple regression is to learn more about the relationship between several independent or predictor variables and a dependent variable. The general form of the regression equation is as follows:

$$
Y=b_{0}+b_{1} X_{1}+\ldots+b_{3} X_{3}+\ldots .+b_{n} X_{n}
$$

Where $Y$ is the dependent variable representing draft, $b_{0}$ is a constant, where the regression line intercepts the y-axis, $b_{1} \ldots b_{n}$ are regression coefficients, representing the amount of changes of the dependent variable $\mathrm{Y}$, when the corresponding independent changes one unit and $X_{1}-X_{n}$ are independent variables referring to the soil and working parameters in this study.

Using Excel spreadsheet, multiple regression analysis was carried out to correlate the simulated draft to three soil conditions including: soil moisture content, soil bulk density and soil texture index, besides two working parameters including plowing depth and speed were added to the soil parameters in the model. A multiple regression model to predict moldboard plow's draft is given as:

$$
\begin{array}{r}
H(k N / \text { body })=-12.584-0.0918 M C+6.363 B D+0.162 d \\
+0.121 V+9.798 S T I \quad R^{2}=0.450
\end{array}
$$


Where $\mathrm{MC}$ is soil moisture content (\% db), BD is soil bulk density $\left(\mathrm{g} / \mathrm{cm}^{3}\right)$, STI (dimensionless) is soil texture index as calculated by Eq. (2), $\mathrm{d}$ is plowing depth $(\mathrm{cm})$ and $\mathrm{V}$ is plowing speed $(\mathrm{km} / \mathrm{h})$.

\section{Models performance}

For evaluating the performance of the ANN model and regression equation, difference between the predicted and simulated values of the draft was analysed. This difference can be evaluated through any of the following error values: root mean square error, mean absolute error and mean relative error as follows:

$$
\begin{aligned}
& M A E=\frac{1}{N} \times \sum_{i=1}^{i=N}\left|E_{\text {iobs }}-E_{\text {ipre }}\right| \\
& R M S E=\sqrt{\frac{\sum_{i=1}^{i=N}\left(E_{i o b s}-E_{i p r e}\right)^{2}}{N}} \ldots \\
& M R E=\frac{100}{N} \times \sum_{i=1}^{i=N}\left(\frac{E_{\text {ipre }}-E_{\text {iobs }}}{E_{\text {iobs }}}\right)
\end{aligned}
$$

Where $\mathrm{E}_{\text {iobs }}$ and $\mathrm{E}_{\text {ipre }}$ are simulated or measured and predicted draft, $\mathrm{N}$ is number of observations, MAE is mean absolute error, RMSE is root mean square error and MRE is mean relative error. In addition, the coefficient of determination $\left(\mathrm{R}^{2}\right)$ was selected to measure the linear correlation between the calculated and the predicted values. The optimal $\mathrm{R}^{2}$ value is unity.

\section{RESULTS AND DISCUSSION}

\section{Performance of the models}

In this paper, ANN and MLR models were applied. The ANN model with 5 neurons in the input layer, 8 neurons in the hidden layer and one neuron in the output layer for the prediction of draft was implemented. The inputs to the ANN model were plowing depth, plowing speed, soil texture index, soil moisture content and soil bulk density. However, statistical analysis was carried out using Excel 2007 software package to 
regress the draft of a moldboard plow as dependent variable on the soil and working parameters (as independent variables) including soil moisture content, soil bulk density, soil texture index, plowing depth and plowing speed. The multiple regression equation obtained is presented in Eq. (16) using the training data of the ANN model. Value of $\mathrm{R}^{2}$ implies that changes in the independent variables explain $45.0 \%$ of the variation in the draft. The soil texture index has the highest regression coefficient compared to other coefficient of independent variables.

Table (5) illustrates mean absolute error, root mean square error, mean relative error and $\mathrm{R}^{2}$ during building both models. It is clear that RMSE values were 0.359 and $1.442 \mathrm{kN} /$ body when using ANN and MLR models in predicting draft, respectively. Meanwhile, MAE values were less when using ANN model to predict the draft compared to MLR. From Table (5), it is also clear that $\mathrm{R}^{2}$ values during building the two models were 0.966 for ANN model and 0.450 for MLR model. These results demonstrated that ANN model could be considered as an alternative and practical tool for predicting draft requirement of moldboard plow under the selected experimental conditions. Moreover, the encouraged results can push to utilize the developed models to be a tool in evaluation or calculations in farm machinery management process.

To show the power of the two models, testing process was conducted using 96 points which are not used in the training data set. Figure (5) illustrates the relationship between simulated and predicted draft data during testing process. It is clear that testing patterns have low scattering around optimal agreement when using ANN model to predict the draft and reverse result was seen when using MLR in predicting the draft. This finding is proved by calculating error criteria for testing points as illustrated in Table (6). It is clear that $\mathrm{R}^{2}$ values were 0.975 and 0.512 between simulated and predicted data using ANN and MLR models, respectively. Since the variations (MRE) were less than $15 \%$, the developed models are acceptable for gathering agricultural machinery management data for selecting matching implements with tractors, estimating fuel consumption, simulating and comparing the performance of farming systems as reported by Sahu and Raheman (2006). 


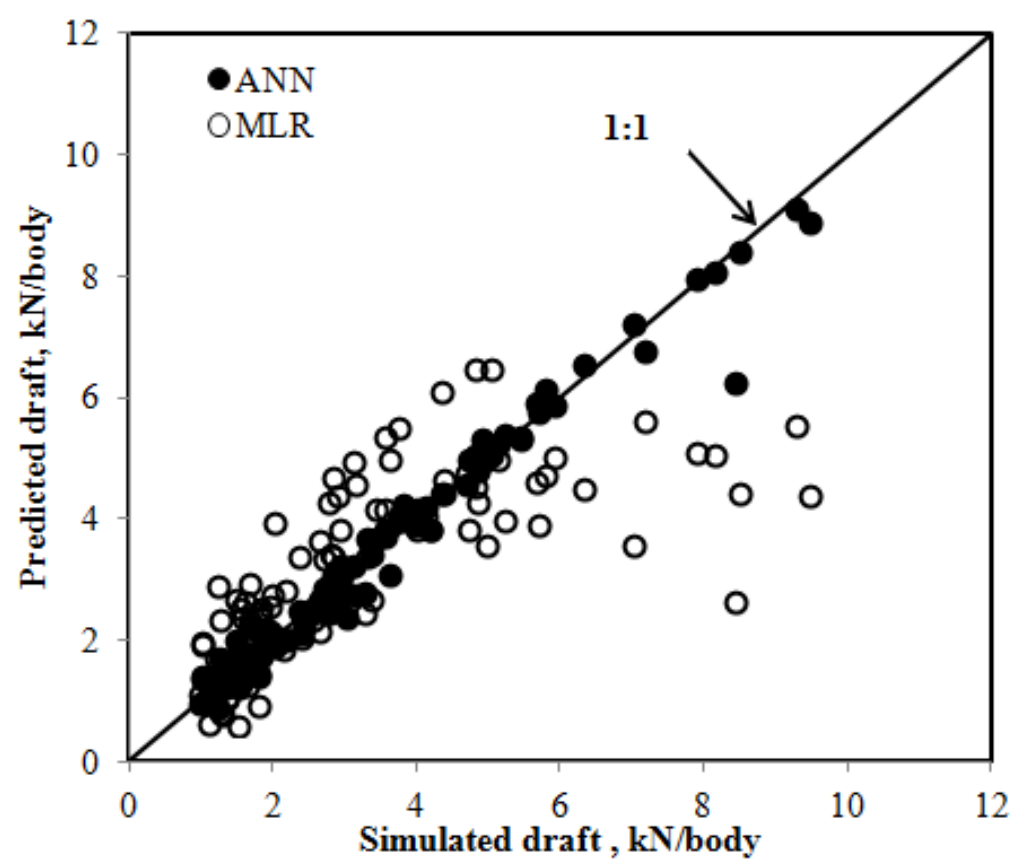

Figure (5). The relationship between simulated and predicted draft data during testing process.

Table (5). Error criteria during building ANN and MLR models.

\begin{tabular}{|l|c|c|c|c|}
\hline \multirow{2}{*}{ Model } & RMSE & MAE & MRE & \multirow{2}{*}{$\mathrm{R}^{2}$} \\
\cline { 2 - 4 } & (kN/body) & (kN/body) & $(\%)$ & \\
\hline ANN & 0.359 & 0.228 & -0.474 & 0.966 \\
\hline MLR & 1.442 & 0.993 & -13.637 & 0.450 \\
\hline
\end{tabular}

Table (6). Error criteria during testing ANN and MLR models.

\begin{tabular}{|l|c|c|c|c|}
\hline \multirow{2}{*}{ Model } & RMSE & MAE & MRE & \multirow{2}{*}{$\mathrm{R}^{2}$} \\
\cline { 2 - 4 } & (kN/body) & $(\mathrm{kN} /$ body $)$ & $(\%)$ & \\
\hline ANN & 0.324 & 0.199 & -1.002 & 0.975 \\
\hline MLR & 1.425 & 0.972 & -8.966 & 0.512 \\
\hline
\end{tabular}

Validation of the models with experimental data and data from literature

To validate both models, draft data from actual field experiment and from literature were used. The field experiment was run using three plowing speed and one plowing depth. The soil and working parameters and measured and predicted draft of the field data are shown in Table (7). Meanwhile, the relationship between plowing speed and measured and predicted draft is shown in Figure (6). It is clear from Figure (6) that a good general agreement between the measured and the predicted draft 
was found. The mean absolute error between the measured and the predicted values of the draft were found to be $5.19 \%$ and $12.32 \%$ for ANN and MLR models, respectively. These variations are due to nature of each model, since ANN deals with nonlinear relationships between input and output variables (Shirgure and Rajput, 2011). The high values for $\mathrm{R}^{2}$ indicate that the variables plowing depth, plowing speed, soil moisture content, soil bulk density and soil texture index can explain most of the variability in the experimental data. In Figure (6) also, the increase in draft is affected by the plowing speed since higher draft was obtained at higher speed.

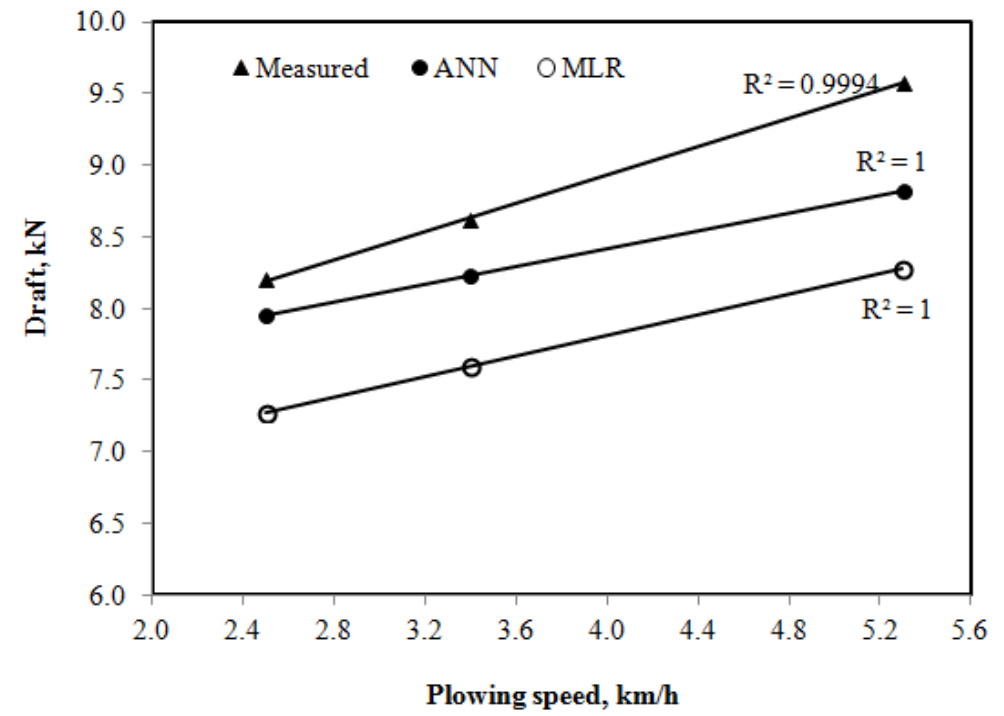

Figure (6). Relationship between plowing speed and measured and predicted draft data from actual field experiment.

Using draft data from Al-Janobi and Al-Suhaibani (1998), both models were validated. In Al-Janobi and Al-Suhaibani (1998), soil bulk density was not found, so, using the calculator on the web was used to get its value from soil fractions as shown in Figure (7). The soil and working parameters and the measured and the predicted draft data of Al-Janobi and Al-Suhaibani (1998) are shown in Table (8). The mean absolute errors between the measured and predicted values of the draft were found to be $-13.19 \%$ and $17.68 \%$ for ANN and MLR models, respectively.

Sensitivity analysis of inputs in ANN model on draft prediction

The Qnet algorithm computed the contribution precent which indicates how the change in each input changes the output prediction. The contribution percentage of the five input variables to the output was 
calculated using the developed ANN model and the results are illustrated in Figure (8). It is clear that soil moisture content is the highest contributed variable (30.687\%). However, impact of soil moisture content on the draft of tillage implements were addressed in several research papers (Gill and Vanden Berg, 1968; Mouazen et al., 2003; Arvidsson et al., 2004). Also, it is clear that all soil parameters together contributed by about $80 \%$ in draft predictions.

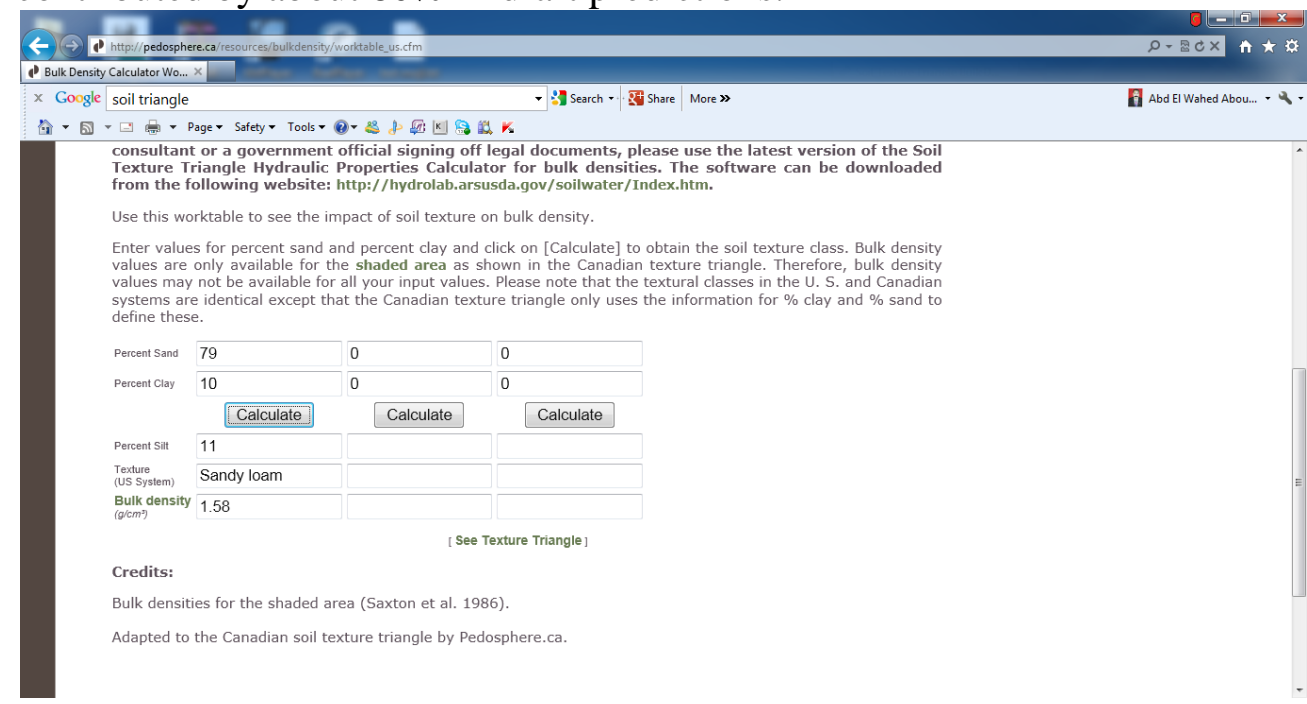

Figure (7). Soil bulk density calculator (http://pedosphere.ca/resources/bulkdensity/worktable_us.cfm).

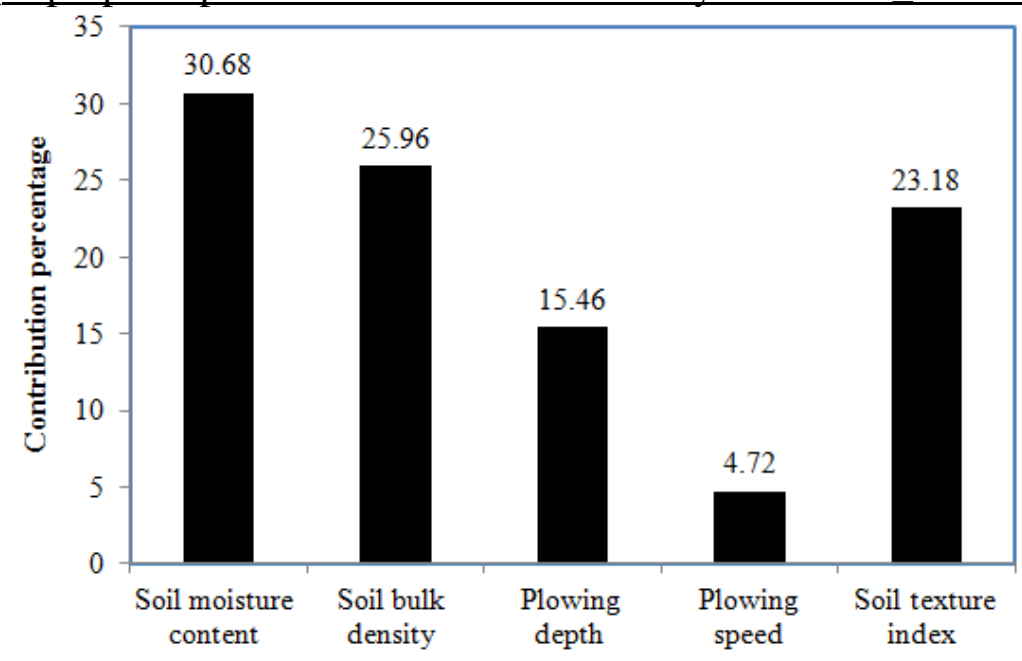

Inputs

Figure (8). Contribution percentage of 5 independent variables used in the 5-8-1 ANN model for prediction of draft of a moldboard plow. 
Table (7). Validation data from field experiment and measured and predicted draft of a moldboard plow.

\begin{tabular}{|c|c|c|c|c|c|c|c|c|c|c|c|c|}
\hline \multirow{2}{*}{$\begin{array}{l}\text { Soil Moisture } \\
\text { content }\end{array}$} & \multirow{2}{*}{$\begin{array}{c}\text { Soil } \\
\text { bulk } \\
\text { Density }\end{array}$} & \multirow{2}{*}{$\begin{array}{l}\text { Plowing } \\
\text { depth }\end{array}$} & \multirow{2}{*}{$\begin{array}{l}\text { Plowing } \\
\text { speed }\end{array}$} & \multirow[t]{2}{*}{ Sand } & \multirow[t]{2}{*}{ Silt } & \multirow[t]{2}{*}{ Clay } & \multirow[t]{2}{*}{ STI } & \multicolumn{3}{|c|}{ Draft $(\mathrm{kN})$} & \multirow{2}{*}{\multicolumn{2}{|c|}{$\operatorname{MRE}(\%)$}} \\
\hline & & & & & & & & \multirow[t]{2}{*}{ Measured } & \multicolumn{2}{|c|}{ Predicted } & & \\
\hline$(\% \mathrm{db})$ & $\left(\mathrm{g} / \mathrm{cm}^{3}\right)$ & $(\mathrm{cm})$ & $(\mathrm{km} / \mathrm{h})$ & $(\%)$ & $(\%)$ & $(\%)$ & $(---)$ & & ANN & MLR & ANN & MLR \\
\hline 7.5 & 1.67 & 15 & 2.5 & 84.6 & 12.4 & 3.0 & 0.238994 & 8.21 & 7.95 & 7.27 & 3.11 & 11.46 \\
\hline 7.5 & 1.67 & 15 & 3.4 & 84.6 & 12.4 & 3.0 & 0.238994 & 8.62 & 8.23 & 7.59 & 4.53 & 11.91 \\
\hline 7.5 & 1.67 & 15 & 5.3 & 84.6 & 12.4 & 3.0 & 0.238994 & 9.58 & 8.82 & 8.28 & 7.94 & 13.59 \\
\hline \multicolumn{11}{|c|}{ Mean } & 5.19 & 12.32 \\
\hline
\end{tabular}

Table (8). Validation data from Al-Janobi and Al-Suhaibani (1998) and measured and predicted draft of a moldboard plow.

\begin{tabular}{|c|c|c|c|c|c|c|c|c|c|c|c|c|}
\hline \multirow{3}{*}{\begin{tabular}{|c|}
$\begin{array}{c}\text { Soil Moisture } \\
\text { content }\end{array}$ \\
$(\% \mathrm{db})$ \\
\end{tabular}} & \multirow{3}{*}{\begin{tabular}{|c|}
$\begin{array}{c}\text { Soil } \\
\text { bulk } \\
\text { Density } \\
\left(\mathrm{g} / \mathrm{cm}^{3}\right) \\
\end{array}$ \\
\end{tabular}} & \multirow{3}{*}{ 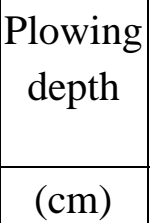 } & \multirow{3}{*}{\begin{tabular}{|c|}
$\begin{array}{c}\text { Plowing } \\
\text { speed }\end{array}$ \\
$(\mathrm{km} / \mathrm{h})$ \\
\end{tabular}} & \multirow{3}{*}{$\begin{array}{l}\text { Sand } \\
(\%) \\
\end{array}$} & \multirow{3}{*}{$\begin{array}{l}\text { Silt } \\
(\%)\end{array}$} & \multirow{3}{*}{$\begin{array}{l}\text { Clay } \\
(\%)\end{array}$} & \multirow{3}{*}{$\begin{array}{l}\text { STI } \\
(---)\end{array}$} & \multicolumn{3}{|c|}{ Draft $(\mathrm{kN})$} & \multirow{2}{*}{\multicolumn{2}{|c|}{$\operatorname{MRE}(\%)$}} \\
\hline & & & & & & & & \multirow[t]{2}{*}{ Measured } & \multicolumn{2}{|c|}{ Predicted } & & \\
\hline & & & & & & & & & ANN & MLR & ANN & MLR \\
\hline 9.5 & 1.58 & 15 & 2.88 & 79 & 11 & 10 & 0.2087 & 5.29 & \begin{tabular}{|l|l|}
6.69 \\
\end{tabular} & 4.25 & -26.56 & 19.72 \\
\hline 9.5 & 1.58 & 15 & 4.752 & 79 & 11 & 10 & 0.2087 & 5.99 & \begin{tabular}{|l|}
7.35 \\
\end{tabular} & 4.92 & -22.76 & 17.84 \\
\hline 9.5 & 1.58 & 15 & 6.048 & 79 & 11 & 10 & 0.2087 & 6.69 & \begin{tabular}{|l|}
7.82 \\
\end{tabular} & 5.39 & -16.85 & 19.45 \\
\hline 9.5 & 1.58 & 15 & 6.984 & 79 & 11 & 10 & 0.2087 & 7.29 & \begin{tabular}{|l|l|}
8.16 \\
\end{tabular} & 5.73 & -11.87 & 21.45 \\
\hline 9.5 & 1.58 & 20 & 2.88 & 79 & 11 & 10 & 0.2087 & 8.03 & \begin{tabular}{|l|}
8.67 \\
\end{tabular} & 6.67 & -8.03 & 16.91 \\
\hline 9.5 & 1.58 & 20 & 4.752 & 79 & 11 & 10 & 0.2087 & 8.56 & 9.35 & 7.35 & -9.19 & 14.17 \\
\hline 9.5 & 1.58 & 20 & 6.048 & 79 & 11 & 10 & 0.2087 & 9.01 & \begin{tabular}{|l|}
9.81 \\
\end{tabular} & 7.81 & -8.92 & 13.27 \\
\hline 9.5 & 1.58 & 20 & 6.984 & 79 & 11 & 10 & 0.2087 & 10.02 & 10.15 & 8.15 & -1.32 & 18.64 \\
\hline \multicolumn{11}{|c|}{ Mean } & -13.19 & 17.68 \\
\hline
\end{tabular}




\section{CONCLUSION}

An attempt was made to develop a simple model to predict draft of moldboard plow. Artificial neural networks (ANN) and multiple linear regression (MLR) models were used to get such simple model. An available excel spreadsheet (Godwin et al., 2007) was used to get the draft data. The soil parameters in this spreadsheet were obtained from actual field experiments. However, plowing speed and plowing depth were assumed. The specifications of the moldboard plow were fed into the spreadsheet. This plow was utilized in the field experiment to get data to validate the developed models. Data are also collected from literature to validate the models. The appropriate ANN model had one hidden layer with 8 neurons. Root mean square error values were 0.359 and 1.442 $\mathrm{kN} /$ body when using ANN and MLR models in predicting draft, respectively. A comparison of experimental draft data showed that the ANN model is able to predict draft force with good accuracy. The variations between measured and predicted draft were around $15 \%$, so the developed ANN model or MLR model is acceptable for gathering agricultural machinery management data for selecting matching implements with tractors, estimating fuel consumption, simulating and comparing the performance of farming systems as reported by Sahu and Raheman (2006).

\section{REFERENCES}

Abas, H., A. Iman and A. Masoumi (2008). Effect of plow share type on moldboard plow performance under different moisture contents and plowing depths. Iranian Journal of Agricultural Sciences, 39(1):8797.

Aboukarima, A. M. (2007). Draft models of chisel plow based on simulation using artificial neural networks. Misr J. Ag. Eng., 24(1): 42-61.

Aboukarima, A.M. (2004). Artificial neural networks configuration for predicting performance of tillage implements under Egyptian conditions. PhD Thesis, Agric. Eng. Dept., Faculty of Agric., Ain Shams University, Egypt. 
Aboukarima, A.M. and A.F. Saad (2006). Assessment of different indices depicting soil texture for predicting chisel plow draft using neural networks. Alexandria Science Exchange J., 27(2): 170-180.

Aboukarima, A.M., M.N. El Awady, A.G. El Kabany and M.H.A. Kabeel (2003). Plows performance under Egyptian conditions depicted by artificial neural networks. Misr J. Agric. Eng., 20 (4): 919-936.

Al-Janobi, A., S. Al-Hamed and A.M. Aboukarima (2010). An excel spreadsheet to estimate performance parameters for chisel plowtractor combination based on trained an artificial neural network. Bulletin USAMV Agriculture, 67(2):1-9.

Al-Janobi, A.A. and S.A. Al-Suhaibani (1998). Draft of primary tillage implements in sandy loam soil. Applied Engineering in Agriculture, 14(4):343- 348.

Al-Janobi, A.A., A.M. Aboukarima and K.A. Ahmed (2001). Prediction of specific draft of different tillage implements using neural networks. Misr J. Agric. Eng., 18 (3): 669-714.

Aluko, O.B. and D.A. Seig (2000). An experimental investigation of the characteristics of and conditions for brittle fracture in twodimensional soil cutting. Soil \& Tillage Research, 57:143-157.

Arvidsson, J. And O. Hillerstrom (2010). Specific draft, soil fragmentation and straw incorporation for different tine and share types. Soil \& Tillage Research, 110:154-160.

Arvidsson, J., T. Keller and K. Gustafsson (2004). Specific draft for moldboard plow, chisel plow and disc harrow at different water contents. Soil \& Tillage Research, 79:221-231.

ASAE Standards (1984). ASAE D203.4: agricultural machinery management data. ASAE, St. Joseph, MI, pp. 213-220.

ASAE Standards (1997). ASAE D497.3: agricultural machinery management data. ASAE, St. Joseph, MI, pp.363-370.

Chung, S.O., K.A. Sudduth, C.Plouffe and N.R. Kitchen (2008). Soil bin and field tests of an on-the-go soil strength profile sensor. Transaction ASABE, 51:5-18. 
El Awady, M.N., A.G. El Kabany, M.H.A. Kabeel, and A.M. Aboukarima (2003). Relative importance of variables affecting chisel-plow performance using neural networks. The $11^{\text {th }}$ Conf. of Misr Society Agric. Eng., 15-16 October, Rice Mech. Centre, Meet El Deeba, Kafer El Sheikh Governorate: 395-407.

El Awady, M.N., A.G. El Kabany, M.H.A. Kabeel and A.M. Aboukarima (2004). Predicting unit draft of tillage implements using statistical models and neural networks. The $12^{\text {th }}$ Conf. of Misr Society Agric. Eng., 15-16 October, Alexandria Univ.: 139249.

El Khadrawy, A.A. (1990). Estimating of used energy in the production of some Egyptian crops. M.Sc. Th., Agric. Mech. Dept., Fac. of Agric., Mansoura Univ.: 71-140.

Elbanna, E.B. (1989). Prediction of specific moldboard plow draft. J. Agric. Sci. , Mansoura Univ., 15 (2):253-265.

Elbanna, E.B. (1992). Tillage tools draft: chisel and moldboard plows. Misr J. Ag. Eng., 9 (4): 491-510.

Formato, A., S. Faugno and G. Paolillo (2005). Numerical simulation of soil-plow moldboard interaction. Biosystems Engineering, 92 (3):309-316.

Gebresenbet, G., E.Zerbini, A. Astatke and P. Kaumbutho (1997). Optimization of animal drawn tillage implement systems: Part2, development of a reversible plow and a ridger. J. agric. Engng Res.,67:299-310.

Gee-Clough, D., M. McAllister, G. Pearson and D.W. Evernden (1978). The empirical prediction of tractor - implement field performance. J. of Terramechanics, 15(2):81-94.

Gill, W. R. and G. F. Van Den Berg (1968). Soil dynamics in tillage and traction. Agricultural Handbook 316, Washington D. C.; USDA Agricultural Research service.

Godwin, R.J., G. Spoorad and P. Leeds-Harrison (1981). An experimental investigation into the force mechanics and resulting solid disturbance of mole plow. J. agric. Engng. Res., 26: 477-497. 
Godwin, R.J., M.J. O’Dogherty, C.Saunders and A.T. Balafoutis (2007). A force prediction model for moldboard plows incorporating the effects of soil characteristic properties, plow geometric factors and plowing speed. Biosystems Engineering, 97:117-129.

Harrigan, T.M. and C.A. Rotz (1995). Draft relationships for tillage and seeding equipment. Applied Engineering in Agriculture, 11(6):773-783.

Hassan, A.E. and A.S.Tohmaz (1995). Performance of skidder tires in swamps-comparison between statistical and neural network models. Transaction ASAE, 38 (5): 1545-1551.

Huijsmans, J. F. M., J. G. L. Hendriks and G. D. Vermeulen (1998). Draft requirement of trailing-foot and shallow injection equipment for applying slurry to grassland. J. agric. Engng Res., 71:347-356.

Imara, Z.M.I. (1996). Development a combined machine for primary and secondary tillage under local conditions. PhD Thesis, Agric. Mech. Dept., Faculty of Agric., Tanta Univ., Kafer El-Sheikh:210-227.

KarimiInchebron, A., S. R. M. Seyedi and R. T. Koloor (2012). Investigating the effect of soil moisture content and depth on the draft, specific draft and drawbar power of a light tractor. International Research Journal of Applied and Basic Sciences, 3 (11): 2289-2293.

Khadr, K. A. A. (2008). Effect of some primary tillage implement on soil pulverization and specific energy. Misr J. Ag. Eng., 25(3): 731745 .

Kheiralla, A.F., A. Yahya, M. Zohadie and W. Ishak (2004). Modelling of power and energy requirements for tillage implements operating in Serdang sandy clay loam, Malaysia. Soil \& Tillage Research, 78:21-34.

Kushwaha, R.L. and Z. X. Zhang (1997). Artificial neural networks modeling of soil-tool interaction.ASAE Paper No. 97-3067, ASAE, St. Joseph, Michigan, USA: 1-11.

Manuwa, S.I. and Ogunlami M.O. (2010). Soil-tool interaction modeling of parameters of soil profile produced by tillage tools. J. Eng. and Applied Sci. , 5:91-95. 
Mouazen, A. M., R. Herman and De B. Josse (2003). Modeling compaction from on-line measurement of soil properties and sensor draft. Precision Agriculture, 4 (2): 203-212.

Mouazen, A.M and H. Ramon (2002). A numerical-statistical hybrid modeling scheme for evaluation of draft requirements of a subsoiler cutting a sandy loam soil, as affected by moisture content, bulk density and depth. Soil \& Tillage Research, 63 (3-4): 155-165.

Mouazen, A.M. and M. Neményi (1998). Review of the finite element modeling techniques of soil tillage. Mathematics and Computers in Simulation, 48: 23-32.

Nadre, R.G. and R.K. Datta (1991). Investigation on forces in three-point linkage of tractor. Journal of Agricultural Engineering, India Society of Agricultural Engineering, Vol. XXVIII, Nos. 1 To 4:254-260.

Oskoui, K. E. and B. D. Witney (1982). The determination of plow draft, part 1: prediction from soil and meteorological data with cone index as the soil strength parameter. J. of Terramechanics, 19: 97106.

Oskoui, K. E., D. H. Rackham and B. D. Witney (1982). The determination of plow draft: part 2, the measurement and prediction of plow draft for two moldboard shapes in three soil series. J. of Terramechanics, 19: 153-154.

Oskoui, K.E. and S.J. Harvey (1992). Predicting cone index from soil physical properties and organic matter content. ASAE Paper No.921056, ASAE St. Joseph, Mich., USA:1-16.

PAES (2001). Philippine Agricultural Engineering Standard (PAES 121: 2001 Agricultural Machinery - Disk Plow - Specifications, 9 p.

Rahman, A., R.L. Kushawaha, S.R. Ashrafizadeh and S. Panigrahi (2011). Prediction of energy requirement of a tillage tool in a soil bin using artificial neural network. ASABE Paper No. 111112. American Society of Agricultural and Biological Engineers, St. Joseph, Michigan, USA.

Roul, A.K., H. Raheman, M.S. Pansare and R. Machavaram (2009). Prediction of draft requirement of tillage implements in sandy clay 
loam soil using an artificial neural network. Biosystems Engineering, 104(4): 476-485.

Sahu, R.K. and H. Raheman (2006). Draft prediction of agricultural implements using reference tillage tools in sandy clay loam soil. Biosystems Engineering, 94 (2):275-284.

Shirgure P. S. and G. S. Rajput (2011). Evaporation modeling with neural networks-A Research review. International Journal of Research and Reviews in Soft and Intelligent Computing (IJRRSIC), 1(2):37-47.

Shrestha, D. S., G. Singh and G. Gebresenbet (2001). Optimizing design parameters of a moldboard plow.J. agric. Engng Res., 78 (4): 377389.

Summers, J.D., A. Khalilian and D.G. Batchelder (1986). Draft relationships for primary tillage in Oklahoma soils. Transaction ASAE, 29(1):37-39.

Tohmaz, A.S. and A. E. Hassan (1995). Application of artificial neural networks to skidder traction performances. J. of Terramechanics, 32 (3): 105-114.

Tong, J. and B. Z. Moayad (2006). Effects of rake angle of chisel plow on soil cutting factors and power requirements: A computer simulation. Soil \& Tillage Research, 88 (1-2): 55-64.

Vesta Services (2000). Vesta Services, Inc. Qnet2000 Shareware, Vesta Services, Inc., 1001 Green Bay Rd, STE 196, Winnetka, IL 60093.

Ward, M.I. and A.I. Moussa (1997). A comparative study of different tillage methods for optimizing corn production. $5^{\text {th }}$ Conf. of Misr Society of Agr. Eng., $9^{\text {th }}$ Sept.1997:173-180.

Zhang, D., Q. Jiang and X. Li (2005). Application of neural networks in financial data mining. International Journal of Computational Intelligence, 1:106-109.

Zhang, Z.X. and R. L. Kushawaha (1999). Application of neural networks to simulate soil-tool interaction and soil behaviour. Canadian Agricultural Engineering, 41(2): 119-125. 


\section{الملخص العربي}

\section{تقييم التقاعل ما بين بيانات تجريبية ومحاكاة للتتبؤ بقوة الثد مقد لمحراث قلاب مطرحي}

\section{د./ عبد الواحد محمد أبوكريمة}

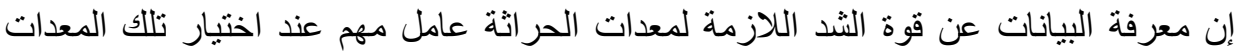
لأداء عمل مزرعي محدد. وحيث أن قياس قوة الثد للمحراث القلاب المطرحي حقليا يتطلب ترنيبات خاصة، لذا من المهم تطوير نماذج يمكن الاعتماد عليها في تقدير هذه القوى. في هذاء

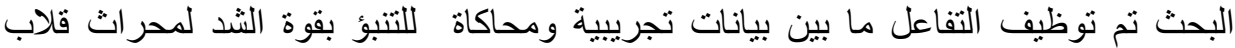
مطرحي، حيث تم تطوير نموذجين مبسطين يعتمدا على الثبكات العصبية الاصطناعية والارتداد الخطي المتعدد. تم استخدام ورقة عمل طورت بو اسطة (Godwin et al., 2007)

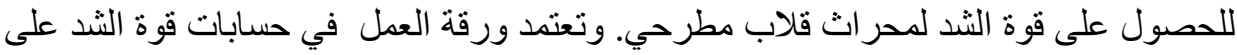

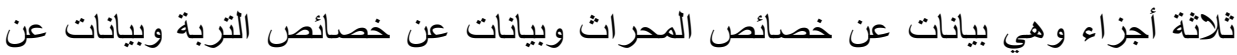

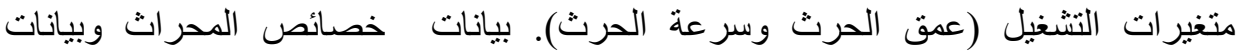
خصائص التربة المطلوبة في ورقة العمل تم الحصول عليها تجريبيا في هذا البحث من خلال

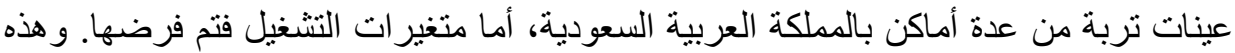

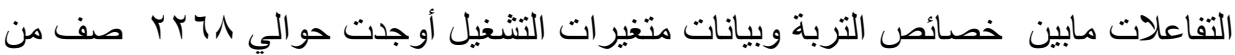

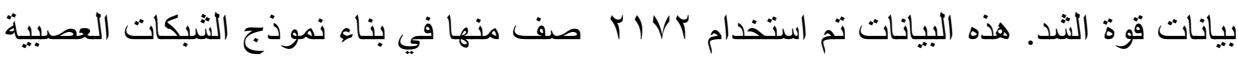
الاصطناعية والارتداد الخطي المتعدد بمساعدة متغيرات دليل قوام التربة و وعمق الحرث

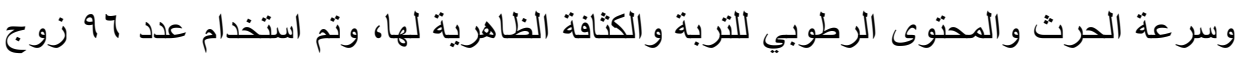

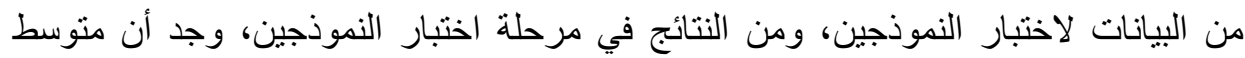
الخطأ النسبي بين قوة الثد التي تم التنبؤ بها من خلال نموذجي الثبكات العصبية والارتداد



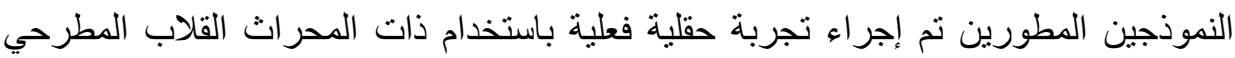

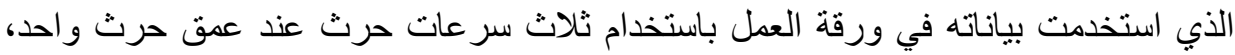
و أوضحت النتائج أن هنالك فرق بين قوة الثد المقاسة و المتنبأ بها من النموذجين المطورين،

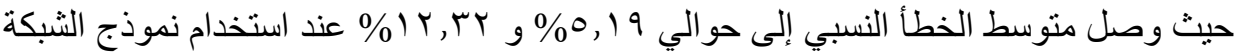
العصبية ونموذج الانحدار الخطي المتعدد على الترنيب. ومن خلال هذه النتائج يمكن استخدام نموذج الثبكة العصبية في استكثاف قيم الثد لمحراث قلاب مطرحي تحت ظروف نرف نربة وتشغيل مختلفة، ويمكن استخدام أي من النموذجين كأداة تقييم في عمليات إدارة الميكنة

*باحث، معهد بحوث الهندسة الزراعية،مركز البحوث الزراعية. حاليا يعمل كأستاذ مساعد بجامعة شقراء بالمملكة العربية السعودية. 